\title{
A Good Example of Positive Results from Bioprospecting without Damaging Environment
}

\author{
Isabel Martínez-Solís
}

Coordinator Head Researcher of SEPLAN, Department of Pharmacy and Biomedical Sciences Research Institute, CEU Cardenal Herrera University, Valencia, Spain

*Corresponding author: Isabel Martínez-Solís, Coordinator Head Researcher of SEPLAN, Department of Pharmacy and Biomedical Sciences Research Institute, CEU Cardenal Herrera University, Valencia, Spain, Tel: 9613690 00; E-mail: isolis@uch.ceu.es

Received date: Jan 20, 2015, Accepted date: Jan 21, 2015, Publication date: Jan 24, 2015

Copyright: (c) 2015 Solis IM. This is an open-access article distributed under the terms of the Creative Commons Attribution License, which permits unrestricted use, distribution, and reproduction in any medium, provided the original author and source are credited.

\section{Opinion Article}

As old researcher and university professor, I know that a continuous controversy between science and economy exists. According to the view of each of parties, development concept is different. This problem is materialized when bioprospecting is applied. As I suggested in an editorial article, bioprospecting is an ancient activity linked to human history, but Society has become a very complex system with conflict of interests, and very often economic interests prevail over social interests. Rose et al. [1] commented that an open discussion taking into consideration diverse views is important to resolve controversies and find convergence. Industry, policy, modern cultures and population must find the best way to benefit fairly and equitably each constituency. Only then will there be a chance of global development because real capacity for change and improvement will be possible. In the framework of the commented problem, the study of Ho and Lau [2] is particularly useful, because they proposed a bioprospecting work line that provides economic benefits through the use of agricultural wastes as optimised carbon source and optimisation of growth conditions for xylanase production by Aspergillus brasiliensis Varga et al. in agitated solid state fermentation. This work is key in discussion about the bioprospecting use as a tool in environmental conservation as well as in creation of economic value for agricultural and forestry assets in countries, mainly in underdeveloped countries.

Xylan, the second most abundant natural polysaccharide, has important industrial applications, particularly the enzymatic hydrolysis. Diversity in the chemical structures of xylan derived from wood, cereal or other plant materials causes a large variety of xylanase with various hydrolytic activities, physicochemical properties and chemical structures. Moreover, xylan derivatives are frequently used to induce the production of xylanase by microorganisms, among them fungi produces higher xylanase activity compared to bacteria and yeasts. According to background information [3-6], xylanase is made by numerous and different fungi. However, in the industrial scale, xylanase production is typically restricted to several species, as Aspergillus spp. Indeed, certain Aspergillus species are selected and optimised for xylanase production in solid state fermentation (SsF). Moreover, these species have many applications in SsF when compared to bacteria and yeast. The physiological, biochemical and enzymological properties of this fungal genus are optima for obtaining a high productivity in the cited fermentation, because fungal hyphae have capacity to penetrate and thrive into solid substances under the controlled conditions. The best Aspergillus species to produce xylanase is $A$. brasiliensis, as Judith and Nei [7] demonstrated, and also makes a large variety of extracellular enzymes, that is why this specie exerts tremendous potentials in many industrial processes [8]. Regarding the fermentation process, it should also be taken into account that the use of SsF for the production of xylanase has several advantages over submerged fermentation $(\mathrm{SmF})$, for example, it is more economical and produces lower contamination risk [9]. In short, xylanase and enzyme-producing microorganisms, as $A$. brasiliensis, are very often used in the management of waste, to degrade xylan to renewable fuels and chemicals, in addition to their use in food, agrofiber, and the paper and pulp industries. Furthermore, oligosaccharides produced by the action of xylanase are used as functional food additives or alternative sweeteners with beneficial properties.

The results from the study of Ho and Lau were consistent with above cited reports, and they described a xylanase production system based on using of $A$. brasiliensis and SsF, with particular conditions of $\mathrm{pH}$, temperature and agitation speed that affect fungi growth and fermentation process, and always using agricultural wastes that come from their country (Malaysia). Thus, the main aims of their study were to find an optimised carbon source from different agricultural wastes, and to assess the effect of different growth conditions on the xylanase production by $A$. brasiliensis via one parameter investigation at a time manner in SsF. The SsF was preferred than SmF due to lesser use of water, higher capability of using cheap and abundant available agricultural wastes as carbon source, and lower contamination risk. Hence, this study was carried out to produce the optimal xylanase activity by $A$. brasiliensis using various agricultural wastes as the prime carbon source in SsF, total of six different agricultural wastes such as barley husk, maize, rice bran, soybean hulls, wheat bran and PKC together with $2 \%$ yeast extract as the nitrogen source were assayed. A fermentation parameter range was also tested in order to determine the best growth conditions for xylanase production by the fungus via SsF. So the study was carried out at different initial medium $\mathrm{pH}$ from 4 to 10 ; and to investigate the optimum temperature for xylanase production, the effect of growth temperature on xylanase production was assayed from 25 to $45^{\circ} \mathrm{C}$. Finally in the study, the optimum agitation speed for the maximum xylanase production was determined from 50 to $200 \mathrm{rpm}$ using the optimised medium formulation and growth conditions obtained from the previous experiments. In order to assess xylanase activity, Ho and Lau used the procedure of Bailey et al. [10] with slight modifications described in the article; to quantify the xylanase activity, one unit of xylanase activity as the amount of enzyme required to produce one micromole of xylose equivalent per minute of enzyme reaction per $\mathrm{mL}$ of enzyme solution under assay conditions was regarded. Total soluble protein concentration was measured using Lowry assay with BSA (Bovine Serum Albumin) used as the standard [11]. The main result obtained from experiments was a higher productivity of xylanase under optimal conditions. Ho and Lau concluded that wheat bran was the most productive and preferable carbon source on xylanase production by $A$. brasiliensis via SsF, initially adjusting the medium $\mathrm{pH}$ to $\mathrm{pH} 6.5$, at the growth 
Citation: Solis IM (2015) A Good Example of Positive Results from Bioprospecting without Damaging Environment. J Biodivers Biopros Dev 2:

Page 2 of 2

temperature range of 25 to $35^{\circ} \mathrm{C}$, preferably at $30^{\circ} \mathrm{C}$, with agitation speed at $150 \mathrm{rpm}$ and fermentation period at $24 \mathrm{~h}$. After to read the article, I conclude that the research aims are successfully achieved in the study.

In my view, this research work allows a direct application of the results to industry because the xylanase obtaining process proposed by Ho and Lau is readily repeatable. Other highlight is the agricultural wastes use as carbon source for avoiding unnecessary exploitation of wild plants from natural ecosystems. Thus, I consider that Ho and Lau have achieved the purpose of the study: to propose xylanase production in large industrial SsF system, using alternative cheap and sustainable carbon source, as wheat bran, and optimal fungi growth conditions.

This work is an example of positive bioprospecting that should help to redirect the controversy about the natural resources use, because the agricultural wastes are also natural resources. Protection and improvement of the environment, landscape and its features are favored because wild natural resources are not directly used.

\section{What is your opinion on this?}

\section{References}

1. Rose J, Quave C L, Islam G (2012) The Four-Sided Triangle of Ethics in Bioprospecting: Parmaceutical Business, International Politics, SocioEnvironmental Responsibitity and the Importance of Local Stakeholders. Ethobiology and Conservation 1:3.
2. Ho H L, Lau L Y (2014) Bioprocessing of agricultural wastes as optimized carbon source and optimization of growth conditions for xylanase production by Aspergillus brasiliensis in agitated Solid state Fermentation (SsF). J Biodivers Biopros Dev 1:3.

3. Matte A, Forsberg CW (1992) Purification, characterization, and mode of action of endoxylanases 1 and 2 from Fibrobacter succinogenes S85. Appl Environ Microbiol 58: 157-168.

4. Wubah DA, Akin DE, Borneman WS (1993) Biology, fiber-degradation, and enzymology of anaerobic zoosporic fungi. Crit Rev Microbiol 19: 99-115.

5. Kulkarni N, Shendye A, Rao M (1999) Molecular and biotechnological aspects of xylanases. FEMS Microbiol Rev 23: 411-456.

6. Qinnghe C, Xiaoyu Y, Tiangui N, Cheng J, Qiugang M (2004) The screening of culture condition and properties of xylanase by white-rot fungus Pleurotus ostreatus. Process Biochemistry 39: 1561-1566.

7. Judith LSL, Nei PJ (2002) Influence of some sugars on xylanase production by Aspergillus awamori in solid state fermentation. Brazilian Arch Biol Technol 45: 431-437.

8. Baker SE (2006) Aspergillus niger genomics: past, present and into the future. Med Mycol 44 Suppl 1: S17-21.

9. Kamble RD, Jadhav AR (2012) Isolation, purification, and characterization of xylanase produced by a new species of bacillus in solid state fermentation. Int J Microbiol 2012: 683193.

10. Bailey MJ, Biely P, Poutanen K (1992) Interlaboratory testing of methods for assay of xylanase activity. Journal of Biotechnology 23: 257-270.

11. Lowry OH, Rosebrough NJ, Farr Al, Randall RJ (1951) Protein measurement with the Folin phenol reagent. J Biol Chem 193: 265-275. 